\title{
RADIOCARBON DATING OF SALT WATER FOUND IN WELLS DRILLED INTO THE BEDROCK IN THE COASTAL AREA OF FINLAND
}

\author{
J. J. Donner and H. Jungner
}

\begin{abstract}
Donner, J. J. and Jungner, H. 1975: Radiocarbon dating of salt water found in wells drilled into the bedrock in the coastal area of Finland. Bull. Geol. Soc. Finland 47, 79-81.

Radiocarbon determinations of salt water drawn from some deep wells drilled into the bedrock confirmed the earlier suggestion that this ground water with a high chloride content is relic water from the time in the development of the Baltic when the coastal areas of Finland were submerged. An exact date cannot be given for the salt water because it has later been mixed with younger ground water.
\end{abstract}

J. J. Donner, Department of Geology and Palaeontology, University of Helsinki, SF-00170 Helsinki 17, Finland.

H. Jungner, Radiocarbon Dating Laboratory, University of Helsinki, SF-00170

Helsinki 17, Finland.

In some parts of Finland the ground water in wells drilled into the bedrock has a rather high chloride content (Laakso 1966). The greatest reported content was in a well at Ylistaro, in the county of Vaasa, where water collected at $600 \mathrm{~m}$ depth had a chloride content of $6300 \mathrm{mg} / 1$ (Laakso 1966). It has been suggested (Salmi 1963; Lahermo 1971) that this water is relic saline water from the time of the Holocene marine stages of the Baltic when the coastal areas of Finland were submerged. This is supported by the fact that the chloride content decreases if much water is drawn from a well with salt water. In an attempt to obtain further evidence about the origin of the salt water the authors performed a radiocarbon dating of the water from some drilled wells, listed in Table 1. The bedrock at the surface consists, at Aura of mica gneiss and kinzigite, at Rautio of quartz diorite and granodiorite, and at Alavieska of feldspar-bearing mica schist, basic plutonic rock and basic porphyrite. Thus, there is probably no great influence on the ages from dissolved carbonates. In order to control this possibility a pair of wells was chosen in each area, one with salt water and another less deep well with freshwater. The distance between wells I and II in Aura is about $1 \mathrm{~km}$ while it is $11 \mathrm{~km}$ between wells I and II at Rautio and Alavieska in Pohjanmaa.

The samples were collected in 1972 . The water was pumped into airtight HD-polyethylene containers and transported to the laboratory, where the $\mathrm{CO}_{2}$ was released with $\mathrm{HCl}$. This was done under a pressure of about $100 \mathrm{~mm}$ and the concentrated $\mathrm{HCl}$ was slowly added at the same time as the sample was mixed and heated to the boiling 
TABLE 1

\begin{tabular}{|c|c|c|c|c|c|}
\hline Sample and location & $\delta \mathrm{C}^{14}$ & $\delta \mathrm{C}^{13}$ & $\Delta$ & Age & Altitude and depth of well \\
\hline $\begin{array}{l}\text { Hel-266, Aura I . . } \\
60^{\circ} 38^{\prime} 30^{\prime \prime} \mathrm{N}, \\
22^{\circ} 35^{\prime} 30^{\prime \prime} \mathrm{E}\end{array}$ & $-393 \pm 15$ & -18.8 & $-401 \pm 16$ & $4010 \pm 210$ & c. $40 \mathrm{~m}$ a.s.l., depth $136 \mathrm{~m}$ \\
\hline $\begin{array}{l}\text { Hel-288, Aura II } \\
60^{\circ} 38^{\prime} 30^{\prime \prime} \mathrm{N}, 22^{\circ} 36^{\prime} \mathrm{E}\end{array}$ & $-194 \pm 16$ & -20.5 & $-201 \pm 17$ & $1730 \pm 160$ & c. $40 \mathrm{~m}$ a.s.l., depth $43 \mathrm{~m}$ \\
\hline $\begin{array}{l}\text { Hel-281, Rautio, } \\
\text { Pohjanmaa I } \ldots . . . \\
64^{\circ} 05^{\prime} \mathrm{N}, 24^{\circ} 12^{\prime} \mathrm{E}\end{array}$ & $-315 \pm 10$ & -14.6 & $-329 \pm 11$ & $3030 \pm 120$ & $\begin{array}{l}55 \mathrm{~m} \text { a.s.1., depth } 113 \mathrm{~m} \text {, } \\
15 \mathrm{~m} \text { of clay on top of } \\
\text { the bedrock }\end{array}$ \\
\hline $\begin{array}{l}\text { Hel-282, Alavieska, } \\
\text { Pohjanmaa II ..... } \\
64^{\circ} 11^{\prime} \mathrm{N}, 24^{\circ} 12^{\prime} \mathrm{E}\end{array}$ & $-161 \pm 16$ & -17.7 & $-173 \pm 17$ & $1410 \pm 150$ & $\begin{array}{l}40 \mathrm{~m} \text { a.s.1., depth } 101 \mathrm{~m} \text {, } \\
6 \mathrm{~m} \text { of clay on top of the } \\
\text { bedrock }\end{array}$ \\
\hline
\end{tabular}

TABLE 2

\begin{tabular}{|c|c|c|c|c|c|c|}
\hline & $\mathrm{pH}$ & Calcium (Ca) & Chloride $(\mathrm{Cl})$ & Natrium (Na) & free $\mathrm{CO}_{2}$ & $\mathrm{HCO}_{3}$ \\
\hline Aura I ............ & 7.7 & $110 \mathrm{mg} / \mathrm{l}$ & $245 \mathrm{mg} / \mathrm{l}$ & $74 \mathrm{mg} / \mathrm{l}$ & $13.2 \mathrm{mg} / \mathrm{l}$ & $200 \mathrm{mg} / \mathrm{l}$ \\
\hline Aura II .......... & 7.6 & 59.5 & 128 & 9.1 & 7.1 & 250 \\
\hline Pohjanmaa I ..... & 7.9 & 530 & 1270 & 380 & 9.2 & 300 \\
\hline Pohjanmaa II . & 8.0 & 26.0 & 120 & 180 & 1.8 & 250 \\
\hline
\end{tabular}

point. The yield of $\mathrm{CO}_{2}$ gas per $100 \mathrm{l}$ of water was c. 41 (NTP). The collected $\mathrm{CO}_{2}$ gas was then treated in the normal way. Because of a rather high radon-content the samples were stored c. 3 months before they were counted. The determinations of $\delta \mathrm{C}^{13}$ were done by $\mathrm{Dr}$. R. Ryhage at the mass-spectrometric laboratory of the Karolinska Institute, Stockholm. The results are given in Table 1 . The results of the chemical analyses are given in Table 2 .

The ages of $c .1500$ years for Aura II and Pohjanmaa II are reasonable for ground water at the depths of about $40 \mathrm{~m}$. Both at Aura and Pohjanmaa sample I is older than sample II. There is, however, no clear relationship between the chloride content and age. The $\delta \mathrm{C}^{13}$ values are also in both cases lower in samples I. But they must both be considered to be mixtures of older salt water and younger ground water.
The low values of the chloride content as well as the $\delta \mathrm{C}^{13}$ values suggest that the salt water only forms a small part of this mixture. Therefore a more accurate estimate of the age of the salt water cannot be made. The results, however, support the assumption that the occurrences of salt water are relics from the Holocene marine stages in the Baltic. The present chloride content has, for instance, in the Baltic at Edenäs, Utö, been determined to $3440 \mathrm{mg} / \mathrm{l}$ and at Harö in the Bothnian Sea to $2924 \mathrm{mg} / 1$ (Ericsson 1973).

According to the geological datings of the emergence of the west coast of Finland, Aura at $40 \mathrm{~m}$ a.s.1. became dry land $c .5500$ years ago and Pohjanmaa at $55 \mathrm{~m}$ a.s.l. c. 4000 years ago. This was at the time of the Litorina Sea stage which began $c .7500$ years ago when the salinity was greater than in the present Baltic. 


\section{Appendix}

At the same time as the above-mentioned determinations were made the water used by the Porvoo waterworks was dated. In this water chloride contents up to $450 \mathrm{mg} / \mathrm{l}$ were recorded during a short period of 1972 . The water used was pumped from the Porvoo river into a reservoir, from which it filtered through the esker by the river to the wells at the waterworks. The results from the dating of the water used at the waterworks (Hel-340) and water taken from the surface of the Porvoo river are given in Table 3. They show that the salt water is not in this case old water. Later investigations of the
TABLE 3

\begin{tabular}{l|c|c|c}
\hline Sample & $\delta C^{14}$ & Age & Chloride $(\mathrm{Cl})$ \\
\hline $\begin{array}{c}\text { Hel-340, } \\
\text { Porvoo I }\end{array}$ & $-44 \pm 16$ & $350 \pm 120$ & $340 \mathrm{mg} / \mathrm{l}$ \\
$\begin{array}{c}\text { Hel-358, } \\
\text { Porvoo II }\end{array}$ & $+44 \pm 14$ & $\begin{array}{l}\text { Recent } \\
(-340 \pm 120)\end{array}$ & 45 \\
\hline
\end{tabular}

ground water occurrences in the area showed that the salt water was sea water, which had penetrated up the river during a period when the outflow was small.

Acknowledgement - The authors wish to thank the Niilo Helander Foundation for financial support.

\section{REFERENCES}

Ericsson, B. (1973) The cation content of Swedish PostGlacial sediments as a criterion of palaeosalinity. Geol. Fören. Stockholm Förh. 95 (2): 181-220.

LAaKso, M. (1966) Kalliokaivojen veden laatu ja antoisuus. Maataloushallituksen insinööriosasto, Maa- ja Vesitekn. Tutkimustoimisto. Tied. 2. 86 p.

LAhermo, P. (1971) On the hydrogeology of the coastal region of southeastern Finland. Geol. Surv. Finland Bull. 252. 44 p.

SALMI, M. (1963) Suolaista vettä kalliokaivosta Seinäjoella (Summary: Saline water from a well drilled into bedrock at Seinäjoki). Geologi 15 (6): 56-60.

Manuscript received, January 10, 1975. 